\title{
歯周病原性細菌のマウス免疫機構に及ぼす影響
}

\author{
涉 谷 俊 昭 \\ 朝日大学歯学部大学院歯学研究科歯周病学専攻 \\ (指導 : 岩山幸雄教授) \\ (昭和 63 年 6 月 17 日受付)
}

\section{Influence of Periodontopathic Bacterial Antigens on the Immune Response in Mice}

\author{
Toshiaki SHIBUTANI \\ Department of Periodontology, School of Dentistry, Asahi University \\ (Director : Prof. Yukio IWAYAMA)
}

This study was designed to investigate the influence of the oral flora on the host's immune mechanism.

After human periodontopathic bacterial antigens were inoculated into the inter-T cell and B cell subpopulations of peripheral blood lymphocytes and serum antibody titer were measured proliferation and the kinetics of $\mathrm{T}$ cell and $\mathrm{B}$ cell in the site of inoculation was observed.

Haemophilus actinomycetemcomitans, Bacteroides gingivalis, Actinomyces viscosus, Fusobacterium nucleatum and Capnocytophaga ochracea were selected as test bacteria and the supernatans from their ultrasonic disintegration were used as antigens which were inoculated into Balb/c mice divided into the initial inoculation group and the booster group.

Peripheral blood lymphocyte subsets were analyzed by flow cytometry using monoclonal antibodies, and serum antibody titers and tissue lymphocytes were measured by the ELISA method and the immunohistochemical technique using biotin-streptavidin, respectively.

Peripheral blood lymphocyte subsets showed a transistory diminution in $\mathrm{T}$ cell in the initial inoculation group. Determination of the helper/suppressor $\mathrm{T}$ cell ratio as a parameter of the immunoregulatory function made clear the coexistence of a high-value group and a low-value group. Specific antibody titers showed an interbacterial group difference. Statistical analysis of tissue lymphocyte subsets did not reveal a distinct difference.

The results suggest that inoculation of a bacterial antigen causes a disturbance the immunoregulatory network.

Key words : Periodontopathic bacteria, Immune response, Lymphocyte subsets, Serum Antibody, Flow cytometry

要旨 : 本研究は生体の免疫機構におよぼす口腔内細菌の影響を明らかにする目的で, ヒト歯周病原性細菌をマウス に接種し, 末梢血リンパ球の $\mathrm{T}$ cell 間および B cell の subpopulation の測定と血中抗体価の測定, 接種局所の T cell, B cell の動態を経時的に観察することにより，免疫機構への影響を検討した。

供試菌には Haemophilus actinomycetemcomitans, Bacteroides gingivalis, Actinomyces viscosus, Fusobacterium

本論文の要旨の一部は第 58 回岐阜歯科学会例会 (1987 年 9 月 19 日), および 第 30 回秋季日本歯周病学会総会 (1987 年 10 月 29 日)において発表した。 
nucleatum, Capnocytophaga ochracea の 5 菌種を選び，その超音波破砕上清を抗原溶液とし，Balb/c マウスに初回接 種群と booster 群とに分け接種した。末梢血リンパ球 subset の解析にはモノクローナル抗体を用いたフローサイト メトリー法で行い，血中抗体価の測定には ELISA 法, 組織中のリンパ球に対してはビオチンーストレプトアビジン を用いた免疫組織化学的手法で行った。

その結果, 末梢血リンパ球 subset の変動では初回接種群で T cell の一過的低下が見られた。免疫調節機能のパ ラメーターである helper/suppressor 比について検討すると, 高い值を示す群と低い值を示す群が存在した。特異抗 体価の測定から各細菌群間で差異が認められた。組織中のリンパ球 subset の解析では明らかな差異は見られなかっ た。

以上の結果から細菌抗原の接種により免疫調節ネットワークに攪乱を生じる可能性が示唆された。

索引用語 : 歯周病原性細菌, 免疫応答, リンパ球サブセット, 血清抗体価, フローサイトメトリー

\section{緒言}

歯周疾患の病因に細菌が大きく関与していることは周 知の事実であり，口腔内細菌そのものが歯周組織に直接 的に侵大するというよりは，むしろその構成成分である 酵素や内毒素が関連していることが示唆されている 一方，これら細菌構成成分に対する生体側の応答として の免疫機構の発現の様式も, 本疾患に重要な役割を担っ ていることが近年強く示唆されるに至っている ${ }^{5 \sim 8)}$ 。

抗体産生系細胞である B 細胞を非特異的に刺激し, 抗 原非特異的な抗体を産生させる能力 Polyclonal B cell activation (PBA) ${ }^{9)}$ は Bacteroides sp., Fusobacterium, Capnocytophaga. sp., H. actinomycetemcomitans などの グラム陰性菌成分に保有されていること や10 18), この PBA の発現機構には B 細胞に直接作用する $\mathrm{T}$ 細胞 非 依存性と $\mathrm{T}$ 細胞 のコントロールを受ける $\mathrm{T}$ 細胞依存性 の場合とがあり, Actinomyces viscosus や Fusobacterium nucleatum の PBA は $\mathrm{T}$ 細胞 依存性であること，また， Tリンパ球が自己の非リンパ球を認識して分裂, 増殖を 起こす現象において自己認識系の一表現であり免疫系の 恒常性の維持に必須の応答であると考えられている Autologous mixed lymphocyte reaction (AMLR) ${ }^{19)}$ は健 常人に比し有意に低いことなど19 25) は, T cell の免疫 調節機能の dysfunction が歯周疾患の病態に深く関わっ ていることを示すものである。

この T cell の免疫調節機構には，そのサブセットで ある helper $\mathrm{T}$ cell, suppressor $\mathrm{T}$ cell, inducer $\mathrm{T}$ cell, cytotoxic T cell などによる量的および機能的要因が中 心になっている。竹内ら ${ }^{26,27)}$ はヒト歯周炎患者の末梢血 リンパ球 subset の分析を行ない, helper T cell/suppressor T cell 比の変動が, 歯周病の病型によって特異
性のあることを報告し，これが先天性要因および後天性 要因に基づくことを示唆している。筆者はこれらの要 因, とくに後天性要因に, 口腔内細菌の影響が関連して いると考え, 数種のヒト歯周病原性細菌を接種したマウ スにおける 免疫調節機能 の変化を末梢血リンパ球の $\mathrm{T}$ cell subset 間および B cell のポピュレーションの測定, 血中抗体価の測定, 接種局所の $\mathrm{T}$ cell, $\mathrm{B}$ cell の動態 を追求することによって検討した。

\section{材料と方法}

\section{1. 実験動物}

5〜 7 週歯の雄 $\mathrm{Balb} / \mathrm{c}$ マウス（静岡実験動物農業協 同組合）を用いた。

飼育は感染を防ぐ目的で他の動物と隔離した部屋の中 で湿度 $60 \%, 25^{\circ} \mathrm{C}$ の条件下のボックス中 (EBAC-S) で 行い, ボックス内はクリーンエアとした。飼料は固型飼 料 (M.F., オリエンタル酵母工業)，飲料水はすべて滅 菌水とし毎日交換した。また実験期間を通してマウスに 全身的な変化は認められなかった。

\section{2. 供試菌株亡調整法}

Haemophilus actinomycetemcomitans SUNY 71813 (H.a), Bacteroides gingivalis ATCC 33277 (B.g), Actinomyces viscosus ATCC 19246 (A.v), Fusobacterium nucleatum ATCC 10953 (F.n), Capnocytophaga ochracea S-3 (C.o) 以上 5 菌株を用いた。

C. ochracea は岡山大学歯学部保存学第二講座 (村山 洋二教授）より，その他の菌株は朝日大学歯学部口腔細 菌学講座 (並河 勇教授) より分与を受けた。

それぞれの菌株は GAM 培地（ニッスイ）に接種後 $\mathrm{N}_{2} 80 \%, \mathrm{CO}_{2} 10 \%, \mathrm{H}_{2} 10 \%$ の嫌気的条件下 (Anaerobic Globe Box 平沢製作所）で $37^{\circ} \mathrm{C}, 7 \sim 10$ 日間培養を行な 


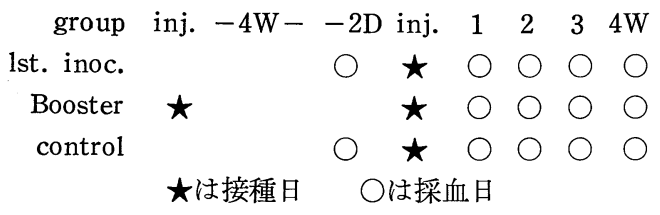

図 1 実験スケジュール

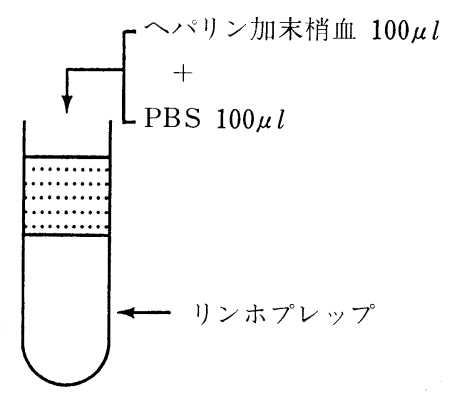

遠沈 $2,000 \times \mathrm{g} 30 \mathrm{~min}$.

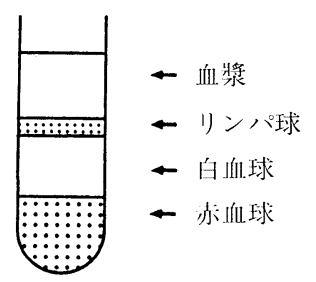

図 2 血液調整法

った。また B. gingivalisに関しては GAM 培地中に 0.1 $\%$ menadione (SIGMA), $0.5 \%$ hemin (半井化学) を加 え，同様の条件で培養を行なった。その後 $7,000 \times \mathrm{G} 30$ 分間で集菌し $0.01 \mathrm{M}, \mathrm{pH} .7 .2$, phosphate buffered saline (PBS) を加えピペッティングと洗浄を 3 回ずつ 行ない約 $1 \times 10^{9}$ 個 $/ \mathrm{m} l$ になるように調整した細菌浮遊 液を $200 \mathrm{~W}, 40$ 分間超音波破砕 (INSONATOR KUBOTA）を行ない菌体を破壊した。

顕微鏡下で菌体が存在しないことを確認後, 再度 $7,000 \times \mathrm{G} 30$ 分間遠心し上清のみを回収し $0.45 \mu \mathrm{m}$ の ミリポアフィルターを通し実験に供した。

\section{3. 接種方法}

booster マウスの予備免疫には前述の細菌破砕上清と Freund's incomplete adjuvant (DIFCO, LAB.) $1: 1$ の割合で十分に混和しエマルジョンとしたものをマウス 上顎右側煩粘膜下に $25 \mu l$ ずっ $30 \mathrm{G}$ の注射針で接種し た。

また booster 時と初回接種マウスにはアジュバントを
表 1 モノクローナル抗体

\begin{tabular}{lll}
\hline FITC 標識 & Thy-1•2 & (Anti Pan-T cell) \\
FITC 標識 Lyt-2 & $\begin{array}{l}\text { (Anti Suppressor/Cytotoxic } \\
\text { T cell) }\end{array}$ \\
PE 標識 & L3T4 & (Anti Helper/Inducer T cell) \\
& I-A $A^{d}$ & (Anti Pan-B cell) \\
\hline
\end{tabular}

用いずそのまま同左側に $25 \mu l$ ずつ接種した。control 群には pH. 7.2 PBS を同量接種した。

\section{4. 実験スケジュール}

各細菌接種群 (各 5 匹), controt 群 (20匹) に対して 図 1 に示すようなスケジュールで接種と採血をおこなっ た。また接種部位の組織内でのリンパ球 subset を観察 する目的で各群マウスの採血日に合わせ 2 匹ずつ屠殺し た。

\section{5. 採血方法}

北川 ${ }^{28)}$ の方法に準じて, 約 $5 \mu l 500$ 万単位のヘパリン ナトリウムを吸引して挨いた滅菌パスッールピペットの 先端を, マウス左側眼窩へ慎重に挿入し, 約 $100 \mu l$ の ヘパリン加末梢血として採取した。

\section{6. 末梢血調整法}

リンパ球の分離には Ficoll-Hypaque 法 (Lymphoprep NYCOMED AS.) による比重遠心法でおこなっ $た^{29)}$ (図 2)。

直径 $8 \mathrm{~mm}$ のチューブに $500 \mu l$ のリンホプレップを 入れ, $200 \mu l$ の希釈末梢血を静かに重層した後に 2,000 $\times \mathrm{G} 30$ 分間遠心した。

図 2 に示すようにその上清 (plasma) $100 \mu l$ は ELISA 法による抗体価の測定に用い, リンパ球分画は慎重に回 収した後に PBS で数回洗浄し約 $1 \times 10^{4}$ 個の浮遊液にな るように算定, 調整した。

\section{7. リンパ球 Subpopulation の分析法}

モノクローナル抗体 (MoAb) には, FITC 標識抗 Thy 1.2 抗体 (Rat IgG) ${ }^{30,31)}$, FITC 標識抗 Lyt 2 抗体 (Rat IgG) $\left.{ }^{30} 33\right)$, PE 標識抗 L3T4 抗体 (Rat $\left.\operatorname{IgG}\right)^{34,35)}$,), 抗

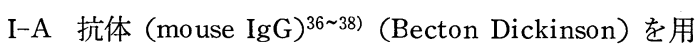
いた（表 1)。

リンパ球 $10^{3}$ 個に対してそれぞれのモノクローナル抗 体を $1 \mu l$ の割合で加え $4^{\circ} \mathrm{C} 30$ 分間反応させた後, PBS で洗浄し再度浮遊液として測定に供した。I-A ${ }^{\mathrm{d}}$ 抗体は 未標識抗体のため, さらに 2 次抗体としてアフィニティ 一精製 FITC 標識抗マウス IgG (Goat TAGO) を引き 続き 30 分間反応させ, その後同様に調整した。細胞の 膜抗原の変性を防ぐ目的で, 保存せずに調整後ただちに 
測定を抗こなった（図 3)。

螢光陽性細胞率の分析には Flow Cytometory (FCS-1 日本分光）を用いた ${ }^{39}$ 。前方散乱光と $90^{\circ}$ 側方散乱光に より mapping し, そのリンパ球分画の細胞群に gating して, この区域内の細胞の螢光強度を測定した。測定に 際し $1 \times 10^{3} \sim 3 \times 10^{3}$ 個のリンパ球をカウントした。螢 光陽性の border line は高瀬 ${ }^{40)}$ の方法に準じて決定した (図 4)。統計処理に際し各抗体陽性率は Thy $1.2^{+}$cell との比としてあらわした。

\section{8. 抗体価の測定方法}

5. で分離した血漿 (Plasma) 中の細菌抗原に対する 抗体価を Enzyme Linked Immuno Sorbent Assay (ELISA) 法 ${ }^{41)}$ で測定した（図 5)。

$$
\text { まず } 96 \text { 穴マイクロタイタープレート（住友ベークラ }
$$

イト）の各 well に 100 倍希採した各細菌の超音波処理 上清を $50 \mu l$ ずつ入れ $4{ }^{\circ} \mathrm{C}$ で over night し吸着させた。 PBS で洗浄後, $1 \%$ BSA (Bovin serum alubumin)-炭 酸 bufferを $200 \mu l$ ずつ各 well に加え室温, 1 時間, で coating した。PBS-T (pH 7.2 PBS-0.05\% Tween 20) で洗浄し, 各群のマウス希釈血漿 $(1: 10)$ を $50 \mu l$ ずつ well に入れ 1 時間反応させた。反応後, PBS-T で 洗浄し, ペルオキシダーゼ標識抗マウス IgG (1:500), IgM (1:500) (Goat. TAGO) を 1 時間反応させ, PBS$\mathrm{T}$ で洗浄し $o$-PDA (o-Phenylenediamine Dihydro- chloride 半井化学) pH. 5.0 クエン酸ーリン酸紱衝液を 加え 30 分後 $\mathrm{H}_{2} \mathrm{SO}_{4}$ で反応を止めた。直ちに EIA リー ダー (BIO-RAD) により, OD $492 \mathrm{~nm}$ で吸光度を測定し た。また抗体価の測定は全て triplicate でおこなった。

\section{9. 免疫組織学的検索 ${ }^{42)}$}

屠殺時にマウス右側上頷の接種部位を biopsy し Tissue-Tek II に包埋し $-30^{\circ} \mathrm{C}$ で凍結させ, Cryostat (MINOTOME DAMON/IEC DIVISION) で 5 8 $\mu \mathrm{m}$ の 連続切片とし, アセトン固定した後に PBS 中に 20 分間 浸漬した。以下通常の酵素抗体法に従い, 内因性ペルオ キシダーゼを除去するために $0.3 \% \mathrm{H}_{2} \mathrm{O}_{2}$ を 10 分間反応 させた。一次抗体には前述の抗 Thy 1.2, Lyt 2, L3T4,

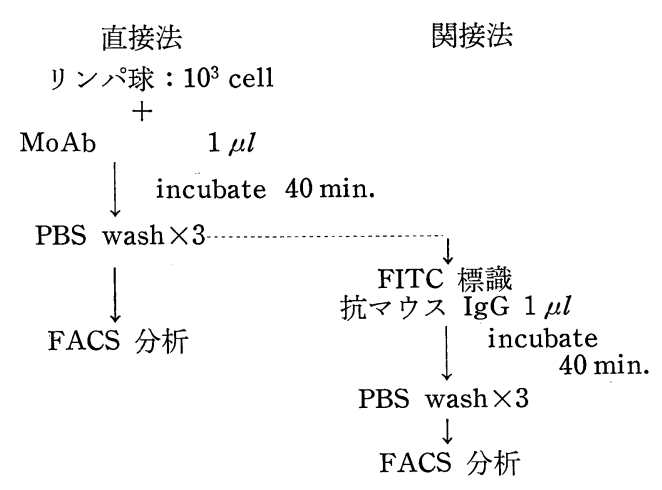

図 3 末梢血リンパ球の染色法

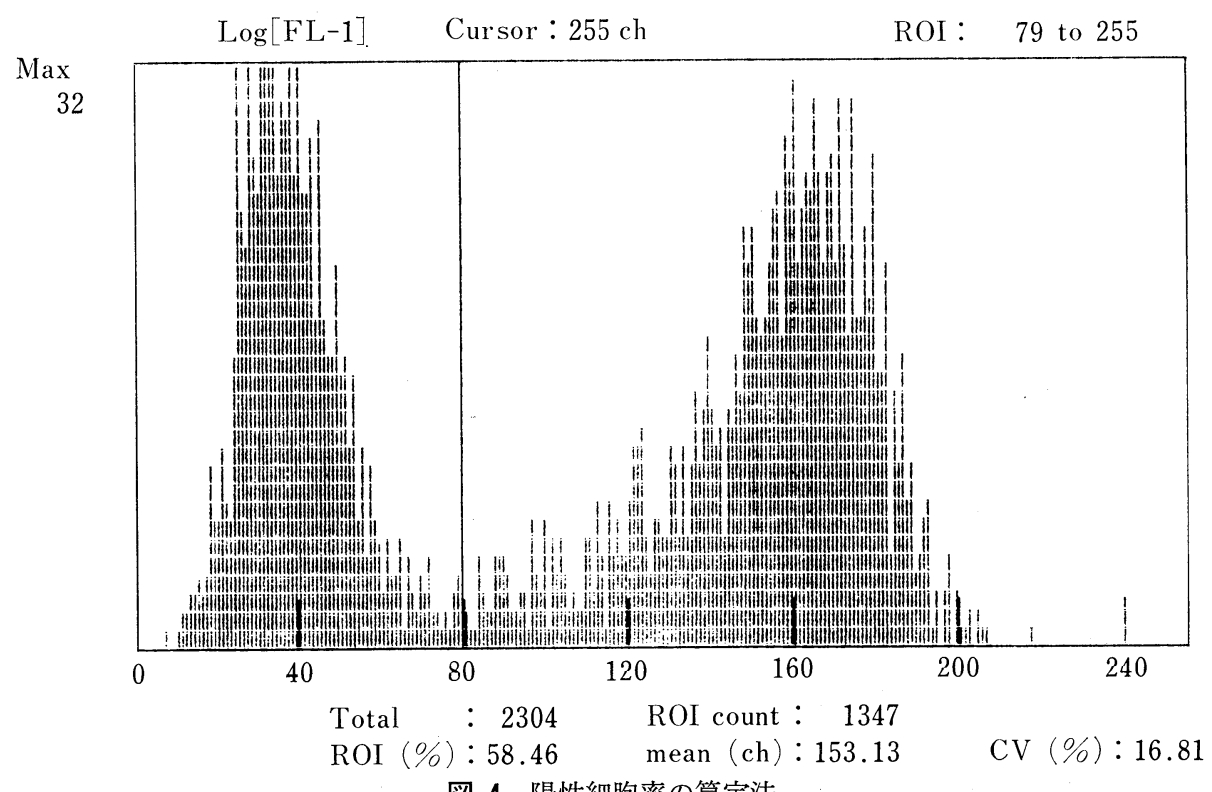

図 4 陽性細胞率の算定法

螢光陽性の border line は高瀬 ${ }^{40)}$ の方法に準じて決定した 


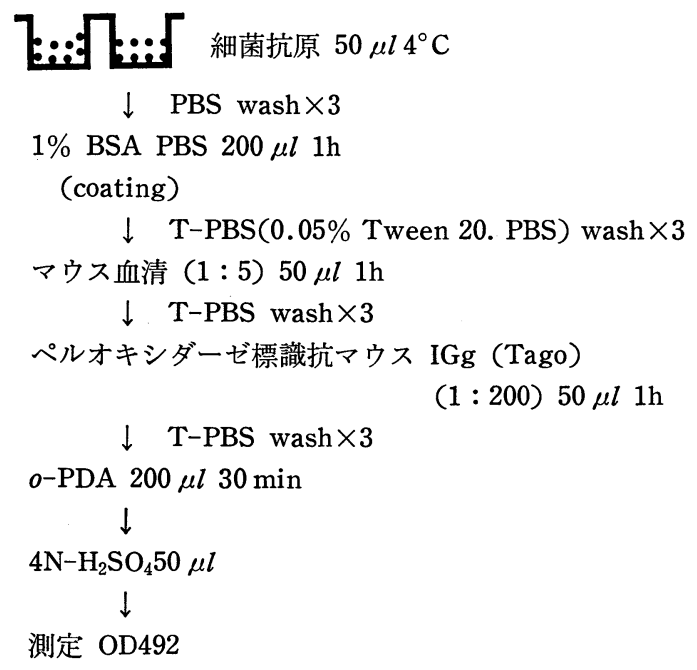

図 5 血中抗体価の測定方法

Enzyme Linked Immuno Sorbent Assay (ELIZA) 法で行った。

$\mathrm{I}-\mathrm{A}^{\mathrm{d}}$ 精製抗体 (1:100)を用いた。二次抗体以降にはビ オチンーストレプトアビジンシステム (ZYMED) ${ }^{43 \sim 46)}$ を用いた。すなわち二次抗体にはビオチン標識抗ラット イムノグロブリンまたは抗マウスイムノグロブリンを反 応させ PBS で洗浄後, ペルオキシダーゼ標識ストレプト アビジンを反応させた。発色基剤には AEC (3-AminoEthylcarbasol) または DAB (3, 3'-Diamino-benzidintetrahydrochloride）を用い，核染色にはへマトキシリ ンまたはメチルグリーンで行ない，水溶性封入剂で封入 し検鏡した (図 6)。組織上での陽性細胞率の算定には無 作為に 10 視野を選び, その視野内の単核球中の陽 性 細 胞率として算定し, T cell 陽性率との比として表わし た。また同時に対比染色として通常のへマトキシリン・ エオジン $(\mathrm{H} \cdot \mathrm{E})$ 染色も併せておこなった。

\section{結果}

\section{1. 末梢血リンパ球 subset の変動}

表 2 に示すように control 群では Thy $1.2^{+}$cell は $69.66 \pm 3.12 \%$, L3T $4^{+}$cell は $56.03 \pm 3.13 \%$, Lyt $2^{+}$ cell は $15.94 \pm 1.22 \%, \mathrm{I}-\mathrm{A}^{\mathrm{d}+}$ cell は $9.76 \pm 2.01 \%$ で あり L3T4 ${ }^{+} /$Thy $1.2^{+}$は $80.65 \pm 4.50$, Lyt $2^{+} /$Thy $1.2^{+}$ は $22.94 \pm 2.17, \mathrm{I}-\mathrm{A}^{\mathrm{d}+} /$ Thy $1.2^{+}$は $14.05 \pm 2.84$ で, 図 7bに示すように週に 1 度ずつの眼窩からの採血が, リンパ球 subset の変動には影響しないことが明らかと

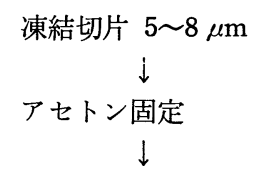

内因性ペルオキシダーゼのブロック $\left(0.3 \% \mathrm{H}_{2} \mathrm{O}_{2}\right) 10 \mathrm{~min}$

$\downarrow \quad$ PBS wash $5 \mathrm{~min} \times 3$

1 次抗体

anti Thy 1.2

anti L3T4

anti Lyt 2

anti $\mathrm{I}-\mathrm{A}^{\mathrm{d}}$

$30 \mathrm{~min}$

$\downarrow \quad$ PBS wash $5 \mathrm{~min} \times 3$

2 次抗体

抗ビオチン化抗ラット (マウス) IgG

$30 \mathrm{~min}$

$\downarrow \quad$ PBS wash $5 \min \times 3$

抗ビオチンストレプトアビジン $30 \mathrm{~min}$

$\downarrow \quad$ PBS wash $5 \mathrm{~min} \times 3$

AEC

$\downarrow \quad$ PBS wash $5 \min \times 3$

ヘマトキシリン

$\downarrow$

封入，検鏡

図 6 免疫組織染色法

Biotin Streptavin system を用いて行った。

表 2 control 群の末梢血リンパ球 subset

\begin{tabular}{lcc}
\hline Antibody & mean \pm S.D. $(\%)$ & $/$ Thy $1.2^{+}$ \\
\hline Thy $1.2^{+}$ & $69.66 \pm 3.12$ & - \\
L3T $4^{+}$ & $56.03 \pm 3.13$ & $80.65 \pm 4.50$ \\
Lyt $2^{+}$ & $15.94 \pm 1.22$ & $22.94 \pm 2.17$ \\
$\mathrm{I}^{-} \mathrm{A}^{\mathrm{d}+}$ & $9.76 \pm 2.01$ & $14.05 \pm 2.84$ \\
\hline
\end{tabular}

なった。

実験群では全ての群で接種後 1 週目に Thy $1.2^{+}$cell の低下がみられ (H.a では $64.12 \% \rightarrow 60.04 \%, A . v$ では $65.18 \% \rightarrow 56.97 \%$, B.g では $71.10 \% \rightarrow 57.92 \%$, C.o で は $72.88 \% \rightarrow 62.88 \%, F . n$ では $70.57 \% \rightarrow 64.20 \%$ ), そ れに相関して I-A ${ }^{\mathrm{d}+}$ cell の増加がみられた。とくに $A . v$ 菌群ではその $\mathrm{I}-\mathrm{A}^{\mathrm{d}+}$ cell の増加は $8.90 \% \rightarrow 24.21 \%$ と 著しく booster 時にも同様に $17 \%$ 前後と高い值を示し た。また C.o 群でも初回接種時に I- $\mathrm{A}^{\mathrm{d}+}$ cell の増加傾 向が認められ 1 週目で $21.84 \%$ であった。しかし Thy $1.2^{+}$cell は初回接種時には経時的に増加し正常值に近 づいいったが, boonter 時には徐々に増加傾向であっ 

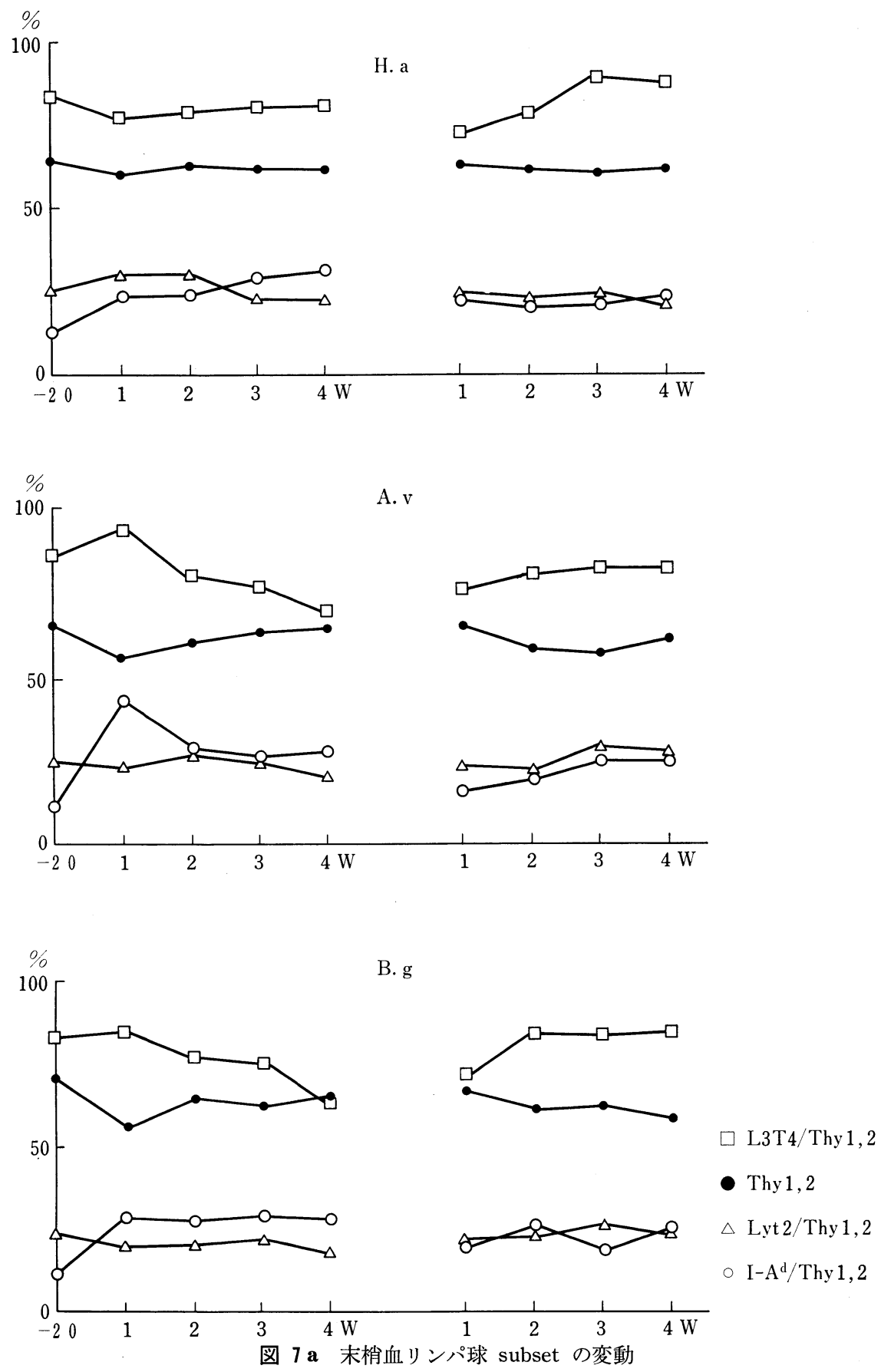

た（図 $7 \mathrm{a}, \mathrm{b}$ )。

免疫調節機能のパラメーターと考えられている helper T cell/suppressor T cell 比 $\left(\mathrm{L} 3 \mathrm{~T} 4^{+} /\right.$Lyt $\left.2^{+}\right)$の変動 に注目してみると（図 8), control 群では $3.52 \pm 0.37$ と
安定しているのに対し, 初回接種後 1 週目に A.v 菌群, $B . g$ 菌群では $4.06,4.11$ と高い值を示した。反対に $H . a$ 菌群は 2.59, C.o 菌群では 2 週目に 2.62 と低い值 を示し, それぞれ control 群に比し有意な差が存在し 

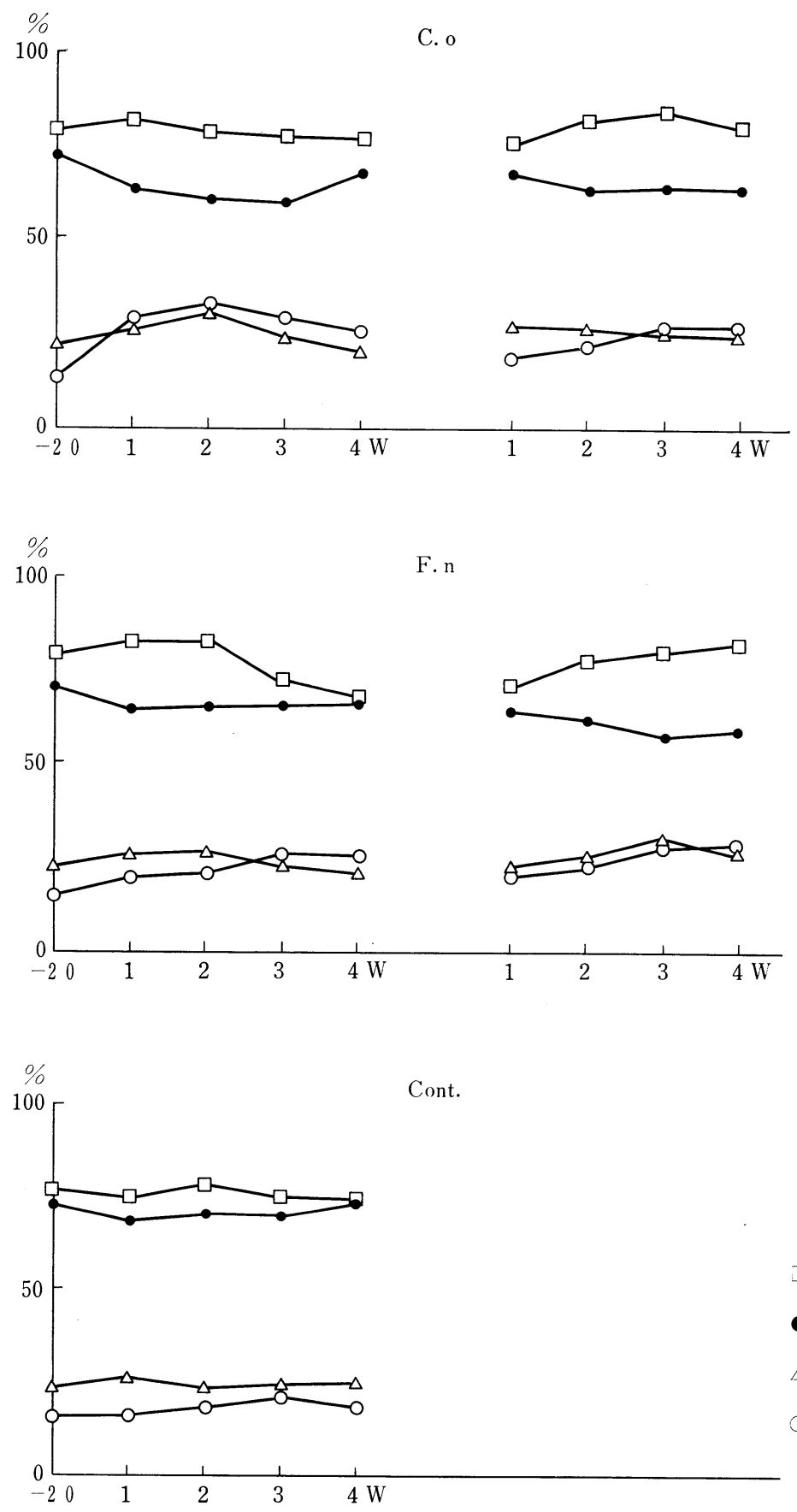

$\sqsupset \mathrm{L} 3 \mathrm{~T} 4 / \mathrm{Thy} 1,2$

- Thy 1,2

$\triangle$ Lyt $2 /$ Thy 1,2

I-A $\mathrm{d} /$ Thy 1,2

図 $7 \mathbf{b}$ 末梢血リンパ球 subset の変動

た。

このように初回接種群では 1 週〜 2 週目に明らかに上 昇する群と ( $A . v, B . g)$, 低下する群 (C.o, H.a, F.n) に
分けることができる。しかし 3 週〜 4 週では比較的接種 前の状態に類似する傾向が見られ 4 週目にはH.a3.56, A.v 3.43, B.g 3.38, C.o 3.83, F.n 3.75 で control 群と 


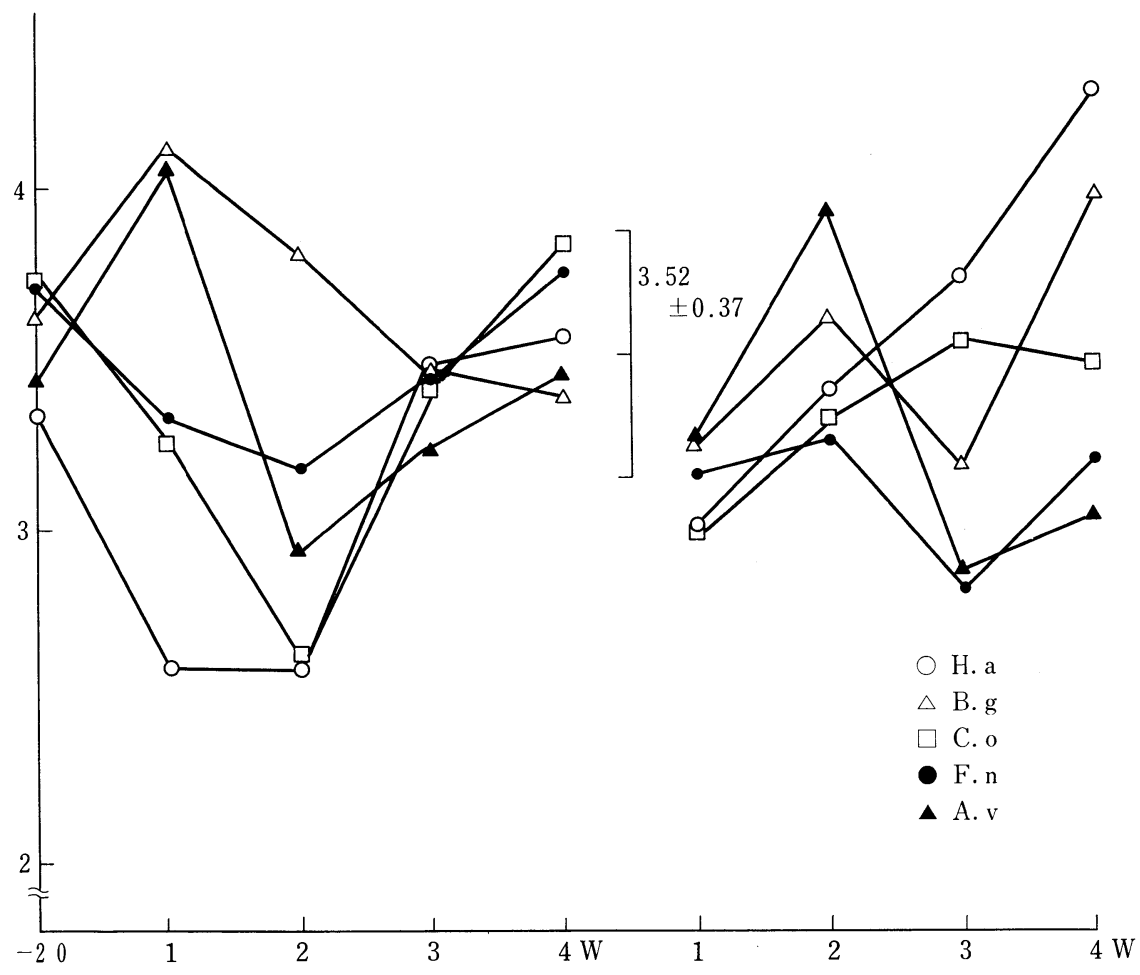

図 8 末梢血リンパ球の $\mathrm{L} 3 \mathrm{~T} 4^{+} / \mathrm{Lyt} 2^{+}$比の変動

表 3 末梢血リンパ球の $\mathrm{L} 3 \mathrm{~T} 4^{+} / \mathrm{Lyt} 2^{+}$比

\begin{tabular}{cccccccccc}
\hline & $-2 \mathrm{D}$ & $1 \mathrm{~W}$ & $2 \mathrm{~W}$ & $3 \mathrm{~W}$ & $4 \mathrm{~W}$ & $1 \mathrm{~W}$ & $2 \mathrm{~W}$ & $3 \mathrm{~W}$ & $4 \mathrm{~W}$ \\
\hline H.a & 3.34 & 2.59 & 2.58 & 3.48 & 3.56 & 3.00 & 3.40 & 3.73 & 4.29 \\
A.v & 3.43 & 4.06 & 2.93 & 3.23 & 3.43 & 3.25 & 3.93 & 2.86 & 3.04 \\
B.g & 3.62 & 4.11 & 3.80 & 3.46 & 3.38 & 3.25 & 3.62 & 3.18 & 3.39 \\
C.o & 3.73 & 3.25 & 2.62 & 3.42 & 3.83 & 3.01 & 3.32 & 3.54 & 3.48 \\
F.n & 3.69 & 3.32 & 3.17 & 3.45 & 3.75 & 3.16 & 3.26 & 2.81 & 3.20 \\
\hline
\end{tabular}

の間に有意差はみられなかった。 booster 時には全群と

も 1 週, 2 週には比較的類似した変動傾向を示している ものの 4 週目にはそのばらつきは大きくなり H.a 4.29, A.v 3.04, B.g 3.39, C.o 3.48, F.n 3.20 と各細菌間で差 異が認められた（表 3 )。

\section{2. 血中抗体価の測定結果 (図 9, 10)}

初回接種時には各群共に初期に $\operatorname{IgM}$ が上昇し, 引き 続き IgG の上昇がみられ, 各細菌群間では比較的類似 した傾向であった。例外としては F.nの IgM が 1 週目 に $0.240 \rightarrow 0.527$ (OD 值)になったものの, 4 週目には 0.374 のレベルにまで低下したことと, H.a の IgG が 3 週，4週になっても $0.405,0.393$ と低い值を保ってい たことである。また booster 時には A.v 菌群では IgM,
$\operatorname{IgG}$ とも 1 週から 4 週まで (IgM；0.713，0.801，0.840， 0.835, IgG；1.187, 1.182, 1.137，1.118）著しく高いレ ベルの抗体価を維持していた。B.g 群で $\operatorname{IgM}$ が 0.539 , $0.557,0.565,0.564$ と若干上昇傾向にあるものの, そ の他の群では IgM に上昇傾向は認められなかった (H.a；0.322，0.327，0.359, 0.351, C.o; 0.426, $0.365,0.368,0.376, F . n ; 0.431,0.337,0.328,0.340)$ 。 IgG に関しては初回接種時の 4 週目よりもやや上昇し ているものの (B.g;0.315,0.528,0.634, 0.638, 0.686, $0.751,0.631,0.699,0.662)$ 比較的安定したレベルを 保っている, H.a 群では $0.494,0.527,0.555,0.583$ と低いレベルであり 4 週目には $A . v$ 群以外の群では比 較的近似した值を示した (H.a 0.583, B.g 0.662, C.o 


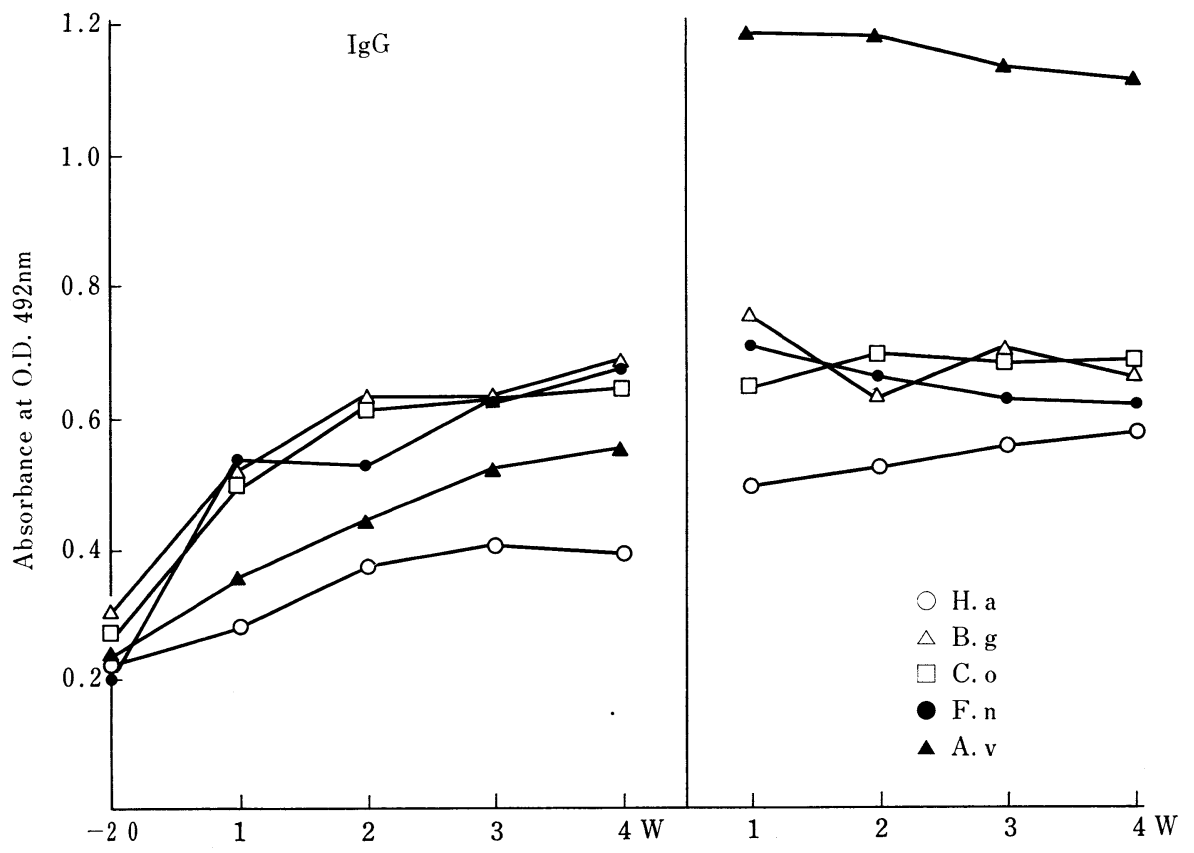

図 9 各細菌抗原に対する特異抗体価の変動 $\operatorname{IgG}$

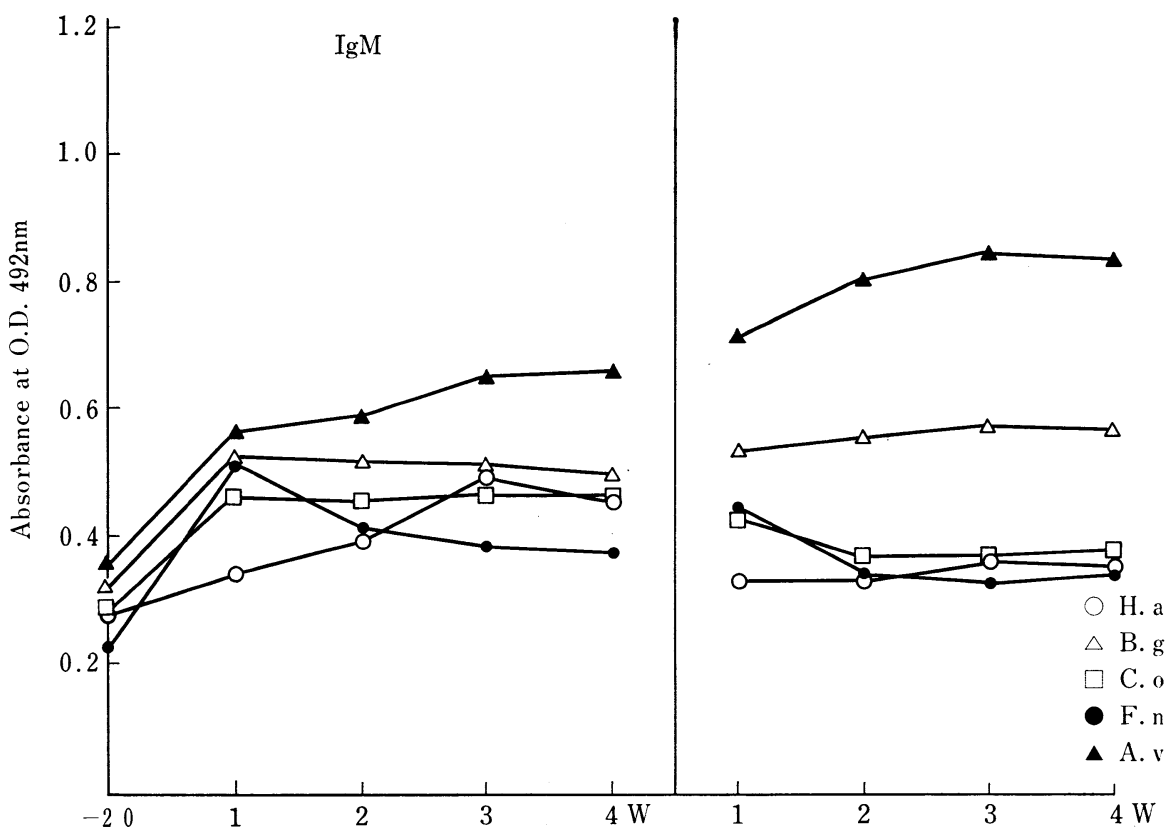

図 10 各細菌抗原に対する特異抗体価の変動 $\operatorname{IgM}$

$0.682, F . n$ 0.621)。

\section{3. 組織内リンパ球 subset の分析結果}

抗原接種局所の組織内リンパ球 subset を免疫組織化 学的手法で観察した結果, 各細菌群間で明らかな差異は
認められなかったものの, 初回接種群と booster 群とを 比較すると, booster 群では局所に浸潤した炎症性細胞 が多く見られ集簇した像を呈する場合が多く観察され, そのような部位に T cell, B cell 系細胞とも多く見ら 


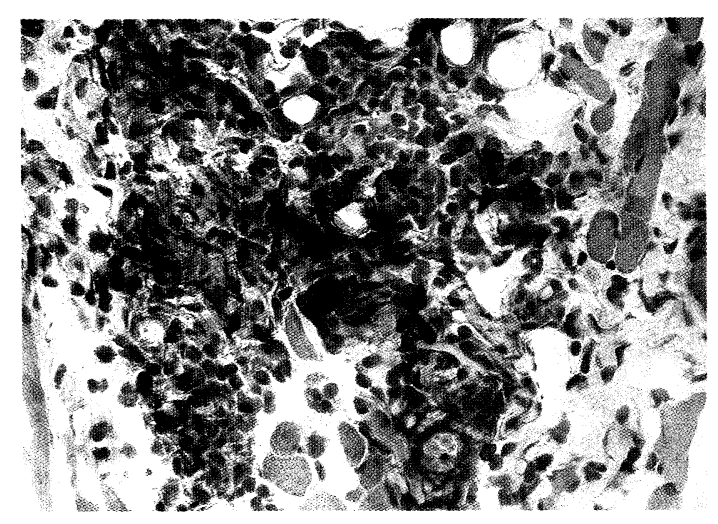

図 11 抗 L3T4 ${ }^{+}$cell

集簇する細胞群の中に陽性細胞が見られる。（×100）

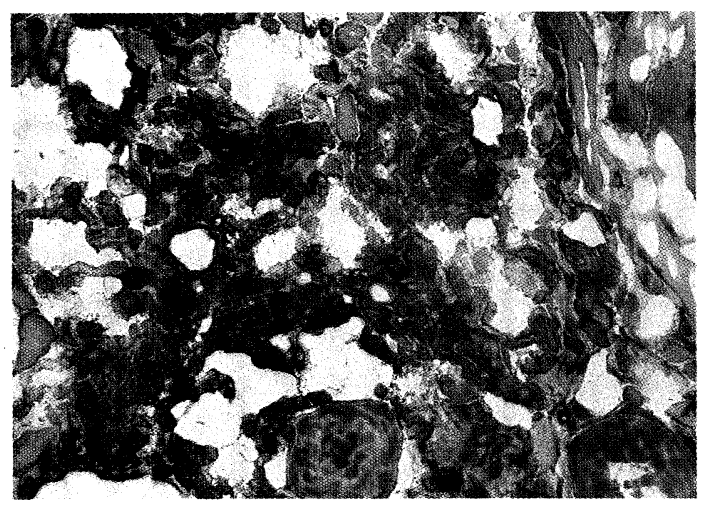

図 12 抗 $\mathrm{I}-\mathrm{Ad}^{+} \mathrm{cell}$

陽性細胞が認められるもの非特異染色も多く見られる

(×100)

れた（図 11, 12)。とくに I-A $\mathrm{A}^{\mathrm{d}+}$ cell は booster 群で高 く, その $\mathrm{T} / \mathrm{B}$ 比は $1.37 \pm 0.80$ と初回接種群の $1.84 \pm$ 0.90 と比較すると有意差はないものの booster 群で低 值を示した。 L3T4 ${ }^{+} /$Lyt $2^{+}$比に注目すると, $1.74 \pm$ $0.41,1.68 \pm 0.74$ と有意差は存在しなかった (図 13,14 )。 しかし図 12 に見られるように I-A $\mathrm{A}^{\mathrm{d}+}$ cell 染色では非特 異染色が多くみられ正確な算出は困難であった。 $\mathrm{H} \cdot \mathrm{E}$ 染色による対比染色でも初回接種群で比較的びまん性の 細胞浸潤像が見られたのに反し booster 群では多形核白 血球，形質細胞，単核球; マクロファージなどを中心に 集簇的にみられその浸潤細胞数もきわめて多かった。ま たその周囲組織には毛細血管の拡張, 膠原繊維束の断裂 が見られ重篤な炎症性像が観察された（図 15～17)。

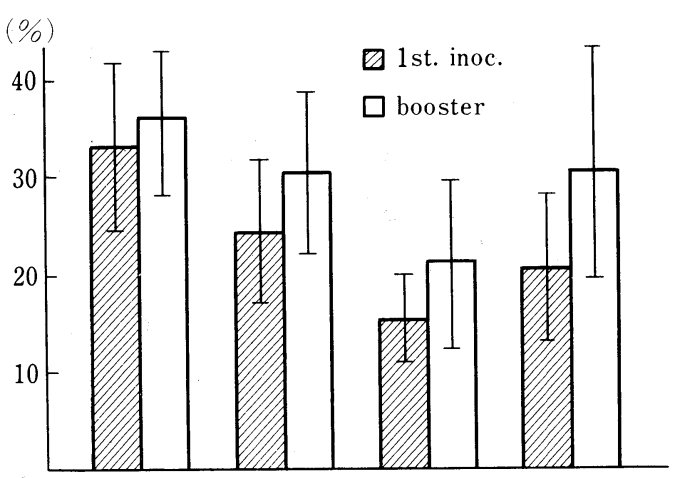

Thy $1-2^{+} \quad$ L3T $^{+} \quad$ Lyt $^{+} \quad \mathrm{I}^{+} \mathrm{A}^{\mathrm{d}+}$

図 13 接種組織中のリンパ球 subset

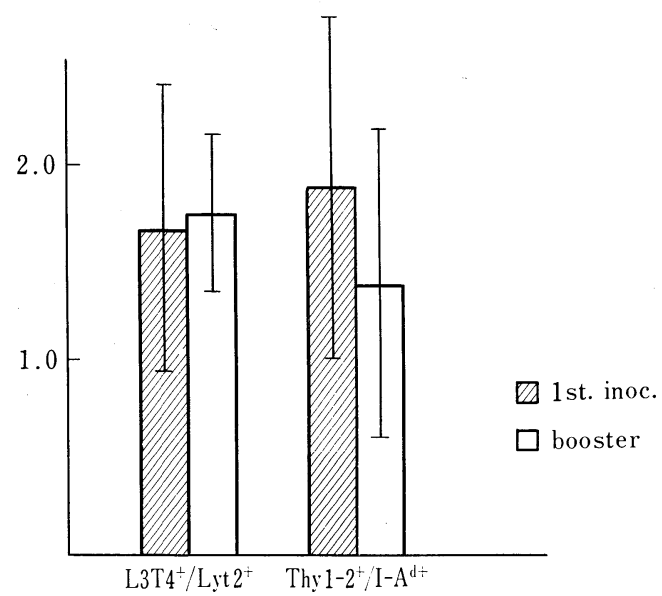

図 14 接種組織中の $\mathrm{L} 3 \mathrm{~T} 4^{+} / \mathrm{Lyt} 2^{+}$比, thy $12^{+} / \mathrm{I}-\mathrm{A}^{+}$比

\section{考察}

細菌感染と宿主の免疫機構は表裏一体をなしている。 宿主の免疫機構の破綻は易感染性をもたらし，さらにそ の感染症をより一層重篤なものにする。歯肉溝内に生息 する多数の細菌を，脆弱な歯肉溝上皮のみで防御してい る歯周組織においては, 万人に感染症発症の 機会があ り, その発症阻止のためには, なおさら正常な防御機能 を必要とする。事実, 永久歯萌出後の歯周組織はすべて subclinical gingivitis を有しているものの, その多くが clinical gingivitis，あるいは periodontitis への進展を 阻止していることは, 宿主の免疫応答が適格に機能して いることの証左である。これを逆説的にみれば，各種歯 周疾患への発症に免疫機能の dysfunction が関連して いることを大いに示唆するものであり ${ }^{47,48)}$, 竹内ら ${ }^{3,4)}$ は 重度進行性歯周炎患者の未梢血リンパ球 subset の解析 


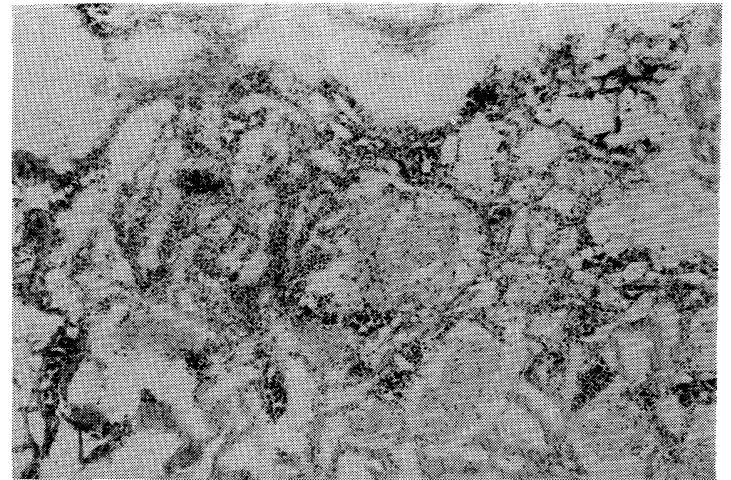

$(\times 25)$

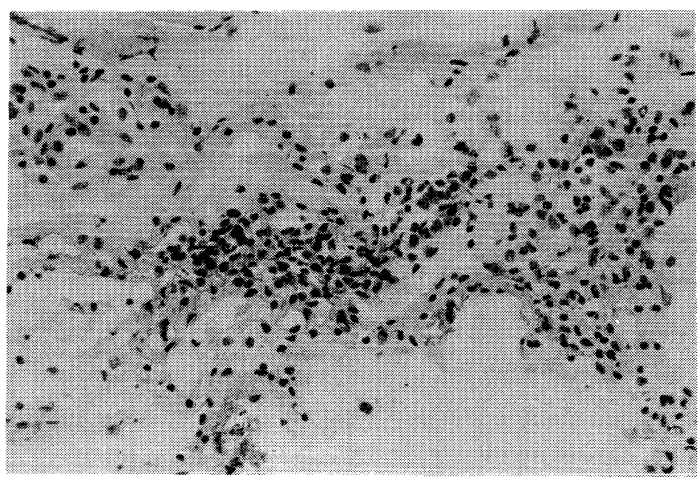

$(\times 100)$

図 15,16 Booster 接種局所で，集簇的な 炎症性細胞浸潤像が見られ結 合組織破壊が著しい。

から患者の pan T cell の低下，および pan B cell の有 意な上昇, またこのような変化が初診時にも治療中にも あまり変動しないことから, 歯周炎罹患患者, あるいは 将来歯周炎に罹患する可能性のある個体には免疫機能の dysfunction が内在していることを予測している。この ような免疫機構の恒常性の dysfunction には, 先天的 要因と後天的要因の 2 面性が考えられる。とりわけ, 後 天的要因では, 細菌性刺激そのものがリンパ球を主とす る免疫损当細胞系の feed-back 機構に影響をちらること が考えられる。

本研究においては, 細菌性刺激が実際に免疫調節機構 に変化を与えるものか否かを，マウスを用いその末梢血 リンパ球および細菌侵襲局所のリンパ球の免疫学的, 免 疫組織学的な解析によって検討した。研究に供した細菌 は, 現在, 歯周病原性細菌として注目されているヒト口 腔内細菌のうちの 5 菌種である。これら細菌の中で $H$. actinomycetemcomitans や Capnocytophaga. sp. は一般

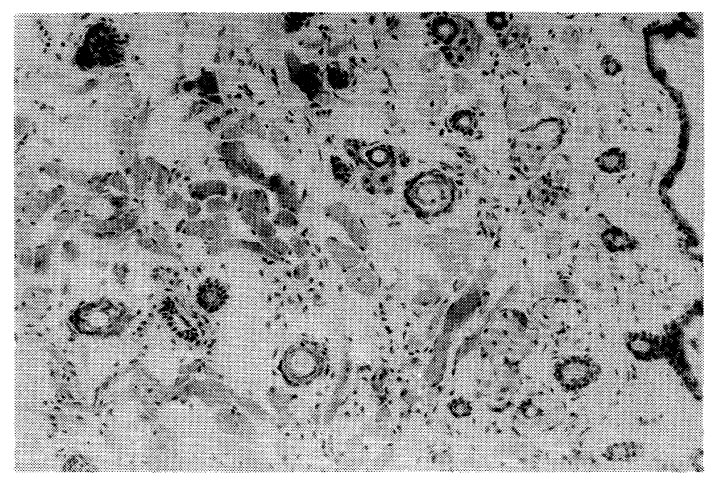

$(\times 50)$

図 17 初回接種局所, びまん性に炎症性 細胞が見られる。

的に限局型若年性歯周炎患者から特異的に見られ, $B$. gingivalis をはじめとする多くの細菌はその他の歯周炎 でよく検出されている

一方, 被験動物としてマウスを用いたが，マウスは他 の実験動物以上に免疫機構がヒトに近く, しかも古くか ら各分野で免疫モデルとして用いられ, 精製抗体等, 免 疫学的研究に必要な材料を容易に入手し得るという利点 がある。とくに, Balb/c マウスは免疫機構の面から, 生 来安定した状態にある動物であるので, 本研究のような 細菌刺激を与えた場合における対比を明確に捉えること ができる66)。

研究に先立って, このような未処置 $\mathrm{Balb} / \mathrm{c}$ マウスの 末梢血リンパ球の経時的変動を 4 週にわたって予備調查 したが, 免疫調節機構のパラメーターとされる helper $\mathrm{T}$ cell/suppressor $\mathrm{T}$ cell 比は $3.52 \pm 0.37$ で正常值を保 った。このことから健常 Balb/c マウスは免疫機構にお いて経時的変動のないことが判明した。実験は 1 回の初 回接種群に加え, 4 週閒後さらにもう 1 回接種の booster 接種群でおこなった。これはヒトの歯肉溝内あるい は歯周ポケット内の常在菌が繰り返し歯周組織に侵襲し つつあることを想定したうえの接種手段である。このよ らに長期にわたって観察した両群の $\mathrm{Balb} / \mathrm{c}$ マウスにお ける末梢血リンパ球の動きを総括的にみると, 初回接種 後 4 週にわたる検索では, ヒトの pan T cell に相当す る Thy $1.2^{+}$cell の一過性の減少と, ヒトの pan B cell に相当する I- $\mathrm{A}^{\mathrm{d}+}$ cell のやや増加が全般傾向として認 められ, さらに, ヒトの helper, inducer $\mathrm{T}$ cell に相当 する L3T4 ${ }^{+}$cell, および suppressor, cytotoxic T cell に相当する Lyt $2^{+}$cell では, 両 cell とも各菌種にお いて control とほぼ同様か, やや減少を認めた。従って 
Thy $1.2^{+}$cell の減少はこの両 cell の低下に基づくもの であることが判明した。

一方，同様のことを booster 接種後についてみると， L3T $4^{+}$cell 22 週後を境にして増加し, 以後プラトーに 達する傾向が認められたのに対し, Lyt $2^{+}$cell は経時的 変動があまり認められなかった。しかし，これらの全般 的な傾向の中にあって, 特定の菌種を接種したマウスに おいて例外的な動きを示した。すなわちこれらを基に実 験マウスの helper T cell/suppressor T cell 比を算出し てみると, control の 3.52 に対して, 初回接種群におい て, $A . v$ 菌および $B . g$ 菌接種群ではそれぞれ $4.06,4.11$ と control より高值を示し, H.a 菌および C.o 菌接種群 ではこれらとは逆に低值を示した。booster 接種群にお いては, とくに H. $a$ 菌接種群が 4 週目に 4.29 と高值を 示した。

このような初回接種後の期間, および booster 接種後 の期間の helper $\mathrm{T}$ cell/ suppressor $\mathrm{T}$ cell 比の高低は それぞれのリンパ球 subset の増減によってもたらされ ることはいうまでもないが，これには，それぞれのリン パ球の増殖における feed-back 機構が関わっている。通 常, 正常状態においては, 各リンパ球 subset は末梢り ンパ臟器において正負の feed-back と機構が交互に働 き, 定常状態を保っている。このような定常状態を保持 する要因は多彩であるが，その中核をなすものはマク口 ファージ $(\mathrm{M} \phi)$ および helper $\mathrm{T}$ cell と suppressor $\mathrm{T}$ cell であることはよく知られ, このために, helper $\mathrm{T}$ cell/suppressor $\mathrm{T}$ cell 比が重要な意味を有することに なる。また，これら細胞が機能する際の実際上の物質は interleukin（IL）であることも知られるようになってき た。この中には, IL-1, IL-2, IL-3 がある。IL-1 はマク ロファージの産生物質であり, 胸腺細胞や末梢 $\mathrm{T}$ cell の分裂, 増殖を促すことから mitogenic protein あるい は Lymphocyte activating factor とも命名され helper T cell に対して T cell growth factor (IL-2) の産生を 誘導し, T 細胞依存性抗体産生を促す。マクロファージ の IL-1 産生を誘導する物質の主たるものは細菌抗原で あり, BCG (Bacillus Calmette-Guérin), Corinebacterium, Streptococcus がよく知られている。一方, IL-2 は 抗原 $\mathrm{T}$ cell, Lyt 1 遅延型 effecter $\mathrm{T}$ cell, Lyt 2 suppressor, killer T cell の増殖を促すこの IL-2 による effecer T cell の誘導過程においてインターフェロン 産生され，これが helper $\mathrm{T}$ cell に対して negative feed-back をもたらす。IL-3 は thy $1^{+}, \mathrm{Lyt}^{+}$cell によ って産生され，骨骾および脾藏に存在する極めて幼弱な
$2 n \alpha$-hydroxysteroid dehydrogenase をもつリンパ球に 作用し，この物質の産生を誘導すると同時に増殖をも促 進させる ${ }^{68 \sim 72)}$ 。

以上のような, 各リンパ球 subset の増減の feed-back 機構は個体発生上, 正常に形成され, 機能している間に おいては，外因性，あるいは内因性の抗原物質から生体 を防御することができる。換言すれば先天的に免疫機能 不全があればこれを行ない得ないことになるが, AIDS (Acquired Immune Deficiency Syndrome) ${ }^{73)}$ の如 $<$, 元来正常な免疫臟器を侵襲し, 後天的に免疫不全を招く こともある。AIDS は極端な例であるが，種々の抗原物 質の持続的侵襲も，重篤度に差はあるものの同様の結果 を引き起こす可能性がある。というのは, 上述のマクロ ファージ, helper T cell, suppressor T cell という免疫 調節回路を後天的に作動させる引き金となるのは抗原物 質にほかならないからで, 現在, これら 3 種の免疫担当 細胞による免疫調節回路のネットワークに関する詳細な feed-back control の仮説の中にも抗原の介在が述べら れており，このネットワークの一要因であることは明ら かである。しかし抗原が如何なる条件下で免疫調節ネッ トワークを破綻させるのかは十分な検討がなされていな い。想定し得る要因には抗原の質と量との関係がある。 たとえば抗原の質が TI 抗原か TD 抗原かによって成立 する免疫ネットワークが違ってくる。また，抗原量の著 しい多眎が免疫トレランスを引き起こすことは周知の事 実であり，トレランスの成立は，見方を変えれば明らか に免疫調節機構の dysfunction を意味するものである。 とくに細菌は, 生体にとってこのような抗原の質と量に よる免疫機構を dysfunctionさせる最も有力な抗原と考 えられる。これは, 菌体成分は多種多様であり, したが って抗原性も複雑多岐にわたると同時に，侵襲の様相も 色々であるからである。このことは口腔内細菌にもあて はまり, とりわけ, 歯肉洪内の細菌は菌種が多種類にの ぼるだけでなく持続感染の可能性が極めて高い。現実 に, 歯肉溝内の細菌は健常人および歯周炎患者ともども がこの特異抗体を有していることはよく知られている。 例えば, 若年性歯周炎患者では H.a 菌やCapnocytophaga. sp. に, びまん性の若年性歯周炎患者や進行性の 重度歯周炎患者では B. gingivalis に，他の歯周炎では Bacteroides, Fusobacterium, Actynomyces, Veillonela, に対する 血中抗体価の上昇することが知られている ${ }^{49 \sim}$ ${ }^{65)}$ 。このことは一応, 歯周病原性細菌を始めとする口腔 内細菌に対する防御の備えができているとを意味するも のであるが，その特異抗体の保有は生体個々によって一 
様ではなく，抗体力価の相違に停まらず，個体間におい て有無の認められることも往々である。この現実もま た, 免疫機構の dysfunction に起因するところ大であ る。今回, 数種のヒト歯周病原性細菌の抗原量を同一と して接種したところ, 初回接種の one shot において, すでに helper T cell/suppressor T cell 比が正常值を ラインとして高低の相反する解析值が得られ，菌種間の 相違を認めた。しかし，その多くは経時的に旧に復した ことから，菌種がリンパ球 subset の動向に特異的な影 響を与えるものの, 侵襲が一過性であるかぎりは subset の変化も一過性であることが判明した。ここにさら に, booster shot を加えると, 持続性の変動が生じるこ とが明らかになった。このことは，反復侵襲の場合に， 細菌抗原は免疫調節ネットワークを䚓乱する可能性を有 していることを示すものである。この際に， booster 接 種後 2 週までは菌種間の相違はあまり認められなかった が, 4 週目に入ると, その相違が明確になり, helper T cell/suppressor T cell 比は $A . a$ および B.g で 4.0 ある いはそれ以上を示し，C.o および F.nは control 群の $3.52 \pm 0.37$ に近似し, A.v はこれより低い值を示した。 つぎに血中 Immunoglobulin の様相をみると, 初回接 種では, いずれの菌種接種群も初期に IgM が上昇し, 後に IgG にスイッチ寸るという一般的傾向を示した。 ここでは H.a 接種群は例外的に IgG が常に低值を示す といら傾向が認められた。

一方, booster 接種群では, 菌種間の差がやや著明に なり, A.v 接種群は $\operatorname{IgM}, \operatorname{IgG}$ とも高值を示し, H.a 接 種群は IgM, IgG とも他と比べて低值を示した。以上の helper $\mathrm{T}$ cell/suppressor $\mathrm{T}$ cell 比々血中 Immunoglobulin 量とを対比してみると, subset 比が高值を示した $H . a$ 接種群では逆に特異抗体価が低く, また subset 比 が低值を示した A.v 菌接種群では特異抗体価が高くな るという逆相関性を認めた。このような subset 比と Immunogloblin 值との関係, 歯周病原性細菌のある群の もの, とくに A.v および H. $a$ は反復感染によって免疫 調節機構を䚓乱する可能性のあることが示唆された。

最後に, 歯周病原性細菌が与える以上のような免疫調 節機構への影響が, 細菌抗原接種局所にどのように反映 してくるのかを調查した。竹内ら ${ }^{26)}$ は七ト成人性歯周炎 患者の末梢血リンパ球の helper $\mathrm{T}$ cell/suppressor $\mathrm{T}$ cell 比の破綻が, その病態を stable $\mathrm{T}$ cell lesion かあるいは progressive B cell lesion に分かつ要 因に成り得ると予測したが, 逆に, 未梢血のリンパ球 subset の動態は病巣局所に反映されないという報告も
みられる ${ }^{74,75)}$ 。筆者の研究では, 菌種接種群においても, 初回接種時に比べて booster 接種時に $\mathrm{I}-\mathrm{A}^{\mathrm{d}+}$ cell が 増加するという共通した傾向がみられたが, 局所での helper $\mathrm{T}$ cell/suppressor $\mathrm{T}$ cell 比には, 末梢血リンパ 球でみられたような菌種間の差異は捉えることができな かった。しかし細菌抗原接種局所では, 単に狭義の免疫 担当細胞以外に多数の細胞が浸潤し交差反応を示すこと や, 病巣を菲薄な一平面でしか捉えられないことが的確 な判断を下し得ないので, 算定值の示すままに判断を下 すことは現在の手法では極めて危険であることも判明し $た^{74 \sim 81)}$ 。以上を小括すると, 今回の実験的研究によって ヒトの歯周病原性細菌として挙げられているものの中に は, 単にその産生物が歯周組織を直接的に障害するのみ ならず, 反復せる侵襲によって, 免疫調節系を著しい全 身疾患の発症に至らない程度に摜乱させ，これが，歯周 組織の免疫機能を低下させその発症や経過に関わるとい う示唆を得た。

\section{結＼cjkstart論}

歯周病原性細菌が免疫調節機構に与える影響について 検討する目的で, 数種の口腔内細菌の超音波破砕可溶性 抗原を Balb/c マウスに接種し, in vivo での免疫調 節機能の全身的および局所的な変化を末梢血リンパ球 subset の変動を中心に血中抗体価, 接種局所の組織中リ ンパ球 subset の変動をも含めて検討したところ以下の 結論を得た。

1. 一般的傾向として末梢血リンパ球 subset の変動 は各細菌接種群ともに初回接種時に $\mathrm{T}$ cell の一過的低 下が認められたものの, booster 時には著明な変化は認 められなかった。免疫調節機能のパラメーターである helper T cell/suppressor T cell 比に注目すると, 初回 接種直後において正常值に対して高低の相反する解析值 が得られ，菌種間の相違を認めたものの，その後経時的 に正常值に近似した值に復した。

2. booster 時には持続性の変動が生じ, 反復接種に より免疫調節ネットワークに何らかの影響を及ぼしてい ることが推測された。

3. また細菌接種後の特異抗体価はすべて IgM から IgG へのスイッチがみられたが, リンパ球 subset 比に 異常な変動を示した菌種接種群ではこの抗体価が低く, 免疫機構の異常がそのまま抗体産生に影響していた。と くに Haemophilus actenomycetemcomitans の如き特定 の菌種においてはこの傾向が強く現れた。 
4. 接種局所のリンパ球 subset の解析の結果, 各細 菌群間で明らかな差異は認められなかったものの booster 時の局所には B cell 系細胞を中心としたリンパ球浸 潤像が強く認められ, 血中リンパ球 subset とは大きく 異なることが明らかになった。

以上の成績より, ヒト歯周病原性細菌の中にはその抗 原性物質が元来正常である生体の免疫機構に対して影響 を及ぼし, その調節機能の攪乱を生ぜしめる可能性のあ ることが示唆された。

$$
\text { 謝 辞 }
$$

稿を終えるにあたり，御懇篤な御指導と御校閲を賜りました 歯周病学講座 岩山幸雄教授に深く感謝いたします。また研究 の実施にあたり終始御懇篤な御指導と御校閲を賜りました口腔 病理学講座 竹内 宏教授に心から感謝いたします。さらに貴 重な細菌の分与ならびに御校閲を賜りました口腔細菌学講座 並河 勇教授, 細菌学的手法の御教示, 御指導を頂きました佐 藤 勝博士に感謝致します。最後に本研究に対して種々御協力 下さった口腔病理講座の皆様および歯周病学講座の皆様に厚く お礼申し上げます。

本研究の一部は昭和 61 年度宮田研究奨励金の補助により行わ れたことを付記する。

\section{文献}

1）Genco, R.J. and Mergenhagen, S.E., 浜田茂幸 : 歯周病の科学, 医歯薬出版, 東京, 1984, 119144.

2) Daly, C.G., Seymour, G.J. and Kieser, J.B. : Bacterial endotoxin; a role in chronic inflamatory periodontal disease? J. Oral Pathol., 9 : 1-15, 1980.

3) 竹内 宏, 堀 泰典, 金久純也, 谷 明, 橋本 政明, 佳川宽典 : 辺縁性歯周炎の免疫病理学的研 究, 第 5 報, その (4), Actinomyces 抽出物接種 による歯周組織の障害性. 歯基礎誌, $25: 31-36$, 1983.

4) 于 世鳳, 堀 泰典, 金久純也, 竹内 宏, 佐藤 勝, 並河 勇: 辺縁性歯周炎と細菌酵素, 第 1 報, Bacterial chondroitinase ABC の歯周組織におよ ぼす影響. 歯基礎誌, 26 : 1984, 326-331， 1984.

5）浜田茂幸 : 歯周病原性細菌の内毒素と宿主の相互 作用 (上). 歯界展望, 70(5) : 1029-1042, 1987.

6）浜田茂幸 : 歯周病原性細菌の内毒素と宿主の相互 作用 (下). 歯界展望, 70(6)：1313-1330， 1987.
7) Newman, M.G. : Current concepts of the pathogenesis of periodontal disease. J. Periodotol., $56: 734-739,1985$.

8) Taubman, M.A. : 歯周疾患と宿主の免疫応答. 歯界展望, 70(2)：351-358, 1987.

9）William, E.P. : 多田富雄 : 基礎免疫学 (上), 東 京大学出版社, 東京, 1986, 157-260.

10) Clegett, J.A., Engel, D. and Chi, E. : In vitro expression of immunogloblin $\mathrm{M}$ and $\mathrm{G}$ subclass by murin B lymphocytes in response to a polyclonal activator from Actinomyces. Infect. Immun., 29 : 234-243, 1980.

11) Bick, P.H., Carpenter, A.B., Holdeman, L.V., Miller, G.A., Ranney, R.R., Palcanis, K.G. and Tew, J.G. : Polyclonal B-cell activation indused by extracts of gram-negative bacteria isolated from periodontally disease sites. Infect. Immun., 34 : 43-49, 1981.

12) Donaldoson, S.L., Bick, P.H., Moore, W.E.C., Ranney, R.R., Burmeister, J.A. and Tew, J. G. : Polyclonal B-cell activating capacities of gram-negative bacteria frequently isolated from periodontally diseased sites. J. periodont. Res., 17 : 569-575, 1982.

13) Mangan, D.F. and Lopatin, D.E. : In vitro stimulation of immunogloblin production from human peripheral blood lymphocytes by soluble preparation of Actinomyces viscosus. Infect. Immun., $31: 236-244,1981$.

14) Mangan, D.F. and Lopatin, D.E. : Polyclonal activation of human peripheral blood B lymphocytes by Fusobacterium nucleatum. Infect. Immun., 40 : 1104-1111, 1983.

15) Kimura, S., Harada, S., Torii, M., Morisaki, I., Koopman, W.J., Okada, H., Michalek, S.M. and McGee, J.R. : Lymphoid cell responses to bacterial cell wall components: murin B-cell responses to a purified cell wall moiety of $A c$ tinomyces. Scand. J. Immunol., $17: 313-322$, 1983.

16) Carpenter, A.B., Sully, E.C., Ranney, R.R. and Bick, P.H. : $\mathrm{T}$ cell regulation of polyclonal B-cell activation induced by extracts of oral bacteria associated with periodontal diseases. 
Infect. Immun., $43:$ 326-336, 1984.

17）原田 泰：Actinomyces viscosus T 14 株の超音波 処理上液が示す多クローン性 B 細胞活性化作用の 発現機構. 日歯周誌, $27: 82-98,1985$.

18）伊藤博夫 : $\mathrm{T}$ 細胞による多クローン性 $\mathrm{B}$ 細胞活性 化の修飾一特に, 多クローン性 IgG 産生の増強 について一. 日歯周誌, $29: 22-36,1987$.

19）木本雅夫 : リンパ球混合培養反応, 大沢利昭, 永 井克孝, 免疫生 化学研究法, 東京化学同人, 東 京, 1986, 199-206.

20) Hellman, B.D. and Stobo, J.D. : The autologous mixed lymphocyte reaction. Gastroenterology, $83: 140-141,1982$.

21) Suzuki, J.B., Park, S.K. and Falkler, W.A. : Immunologic profile of juvenile periodontitis. I lymphocyte blastogenesis and the autologous mixed lymphocyte response. J. periodontol. $5:$ 453-460, 1984.

22) Tew, J.G., Burmeister, J.A., Palcanis, K.G. and Ranney, R.R. : Spontaneous lymphocyte proliferation and the periodontal status of young adults. J. Periodont. Res., $18: 534-540$, 1983.

23) Ranney, R.R., Devski, B.F. and Tew, J.G. : Pathogenesis of gingivitis and periodontal diseases in children and young adults. Pediat. Dent., $3: 89-100,1981$.

24) Seymour, G.J., Boyatzis, S. and Powell, R.N.: The autologous mixed lymphocyte reaction (AMLR) as a possible indicator of immunoregulation in chronic inflammatory periodontal disease. J: Clin. Periodontol., $13: 639-645$, 1986.

25) Cole, K.L., Seymour, G.J., Powell, R.N. : Phenotypic and Functional analysis of $\mathrm{T}$-cell extracted from chronically inflamed human periodontal tissues. J. Periodontol., $58: 569$ $573,1987$.

26）竹内 宏, 田島一範, 渋谷俊昭, 勝谷芳文, 岩山 幸雄, 佐藤 勝, 上田雅俊 : 辺縁性歯周炎と免疫 機構, 第 1 報, 歯周炎患者の免疫機構, 成人性歯 周炎患者と健常人の末梢血りンパ球の解析. 日歯 周誌, 28 : 1054-1062, 1986.

27）竹内 宏, 山中武志, 土居誠司, 田島一範, 金久
純也, 渋谷俊昭, 岩山幸雄, 上田雅俊 : 辺縁性歯 周炎と免疫機構, 第 2 報, 歯周炎患者の免疫 機 構, 重度進行生歯周炎における末梢血リンパ球の 解析. 日歯周誌, $30: 133-141,1988$.

28）北川正保 : マウスよりの採血法, 免疫実験操作法 (A), 日本免疫学会, 東京, 1971，32-33.

29）木下喜博 : リンパ球の分離比重法, 免疫実験操作 法 (A), 日本免疫学会, 東京, 1971, 432-442.

30) Ledbetter, J.A. and Herzenberg, L.A. : Xenogeneic monoclonal antibodies to mouse lymphoid differentiation antigens. Immunol. Rev., $47: 63-73,1979$.

31) Ledbetter, J.A., Rouse, R.V., Mickleman, H.S. and Herzenberg, L.A. : $\mathrm{T}$ cell subsets defined by expression of Lyt-1, 2, 3 and Thy-1 antigens. J. Exp. Med., 152 : 280-290, 1980.

32) Ledbetter, J.A., Evans, R.L., Lipinski, M., Cunningham-Rundles, C., Good, P.A. and Herzenberg, L.A. : Evolutionary conservation of surface molecules that distinguish $\mathrm{T}$ lymphocyte helper/inducer and cytotoxic/suppressor subpopulations in mouse and man. J. Exp. Med., 153 : 310-323, 1981.

33) Ledbetter, J.A., Seaman, W.E., Tsu, T.T. and Her zenberg, L.A. : Lyt-2 and Lyt 3 antigens are on different polypeptide subunits linked by disulfide bonds : Relationship of subunits to T cell cytolytic activity. J. Exp. Med., 153 : 1503-16, 1981.

34) Dialynas, D.P., Quan, Z.S., Wall, K.A., Pierres, A., Quintans, J., Loken, M.R., Pierres, M. and Fitch, F.W. : Characterization of the murin $\mathrm{T}$ cell surface molecule, disignated L3T4, idetified by monoclonal antibody GK 1.5 : Similarity of L3T4 to the human Leu3/T4 molecule. J. Immunol., 131 : 2445-2451, 1983.

35) Dialynas, D.P., Wide, D.B., Marrack, P., Pierres, A., Wall, K.A., Havran, W., Otten, G., Loken, M.R., Pierres, M., Kappler, J. and Fitch, F.W. : Characterization of the murin antigenic determinant, designated L3T4 a, recognized by monoclonal antibody GK 1.5 : Expression of L3T4a by functional $\mathrm{T}$ cell clones appears to correlate primarily with 
class II MHC antigen-reactivity. Immunol. Rev., 74 : 29-39, 1983.

36) Kappler, J., Skidmore, B., White, J. and Marrack, $\mathrm{P}$. : Antigen-inducible, $\mathrm{H}-2$ restricted interleukin-2 producing $\mathrm{T}$ cell hybridomas. Lack of independent antigen and $\mathrm{H}-2$ recognition. J. Exp. Med., 153 : 1198-1208, 1981.

37) Berzofsky, J. and Richman, L. : Genetic control of the immune response to myogloblins. IV. Inhibition of determinant-specific Ir gene-controlled antigen presentation and induction of suppression by pretreatment of presenting cell with anti-Ia antibodies. J. Immunol., 126 : 18981908, 1981.

38) Möller, G., ed. : Hybrid myeloma monoclonal antibodies against MHC products. Transplant. Rev., 47 : 10-20, 1979.

39）佐々木功典: 免疫学的研究のための染色, 天神美 夫, 高橋 学, 野村和弘, フローサイトメトリー ハンドブック, サイエンスフォーラム, 東京, 1984, 175-178.

40）高瀬浩造 : Flow Cytometry を用いた螢光標識モ クローナル抗体染色陽性細胞率の算定方法. 最新 医学, 40 (1) : 45-49, 1985.

41）保井孝太郎：単クローン抗体, ハイブリドーマと ELISA, 講談社, 東京, 1985, 144-183.

42）渡辺慶一, 中根一穂 : 酵素抗体法, 学際企画, 東 京, 1985, 9-20.

43) Chaiet, L. and Wolf, F.S. : The properties of streptavidin, a biotin-binding protein produced by Streptomyces. Arch. Biochem. Biophis., 106 : 1-5, 1964.

44) Woods, G.S. and Warnke, R. : Suppression of endogeneous avidin-binding activity in tissue and its relevance to biotin-avidin detection system. J. Histochem. cytochem., 29 : 11961204, 1981.

45) Hsu, S.M. and Raine, L. : The use of avidinbiotin-peroxydase complex ( $\mathrm{ABC}$ ) in diagnostic and reseach pathology, In : Advances in Immunohistochemistry, R.A. DeLellis, ed., Mason Publishing USA, Inc., New York, 1984, 3142.

46) Warnke, R. and Levy, R. : Detection of T and
B cell antigens with hybridoma monoclonal antibodies: A biotin-avidin-horseradish peroxidase method. J. Histochem. Cytochem., 28 : 771-776, 1980.

47) Theilade, E. : The non-specific theory in microbial etiology of inflammatory periodontal disease. J, Clin. Periodontol., $13: 905-911$, 1986.

48) Shenker, B.J. : Immunologic dysfunction in the pathogenesis of periodontal disease. J. Clin. Periodontol., 14 : 489-498, 1987.

49) Moor, W.E.C. : Microbiology of periodontal disease. J. Periodont. Res., 22 : 335-341, 1987.

50) Slots, J. : Bacterial specificity in adult periodontitis -A summary of work. J. Clin. Periodontol., 13 : 912-917, 1986.

51) Mouton, C., Hamond, P.G., Slots, J. and Genco, R.J. : Serum antibodies to oral Bacteroides asaccharolyticus (Bacteroides gingivalis): relationship to age and periodontal disease. Infect. Immun., $31:$ 182-192, 1981.

52) Mansheim, B.J., Stenstrom, M.L., Low, S.B. and Clark, W.B. : Measurement of serum and salivaly antibody to the oral pathogen Bacteroides asaccharolyticus in human subjects. Archs. Oral Biol., 25 : 553-557, 1980.

53) Naito, Y., Okuda, K. and Takazoe, I. : Immunogloblin G response to subgingival gramnegative bacteria in human subjects. Infect. Immun., $45:$ 47-51, 1984.

54) Listgarten, M.A. et al. : Comparative antibody titers to Actinobacillus actinomycetemcomitans in juvenile periodontitis, chronic periodontitis and periodontally healthy suhjects. J. Clin. Periodontol., 8 : 155-164, 1981.

55) Ebersole, J.L. et al. : Human immune response to oral micro-organism. I. Association of localized juvenile periodontitis (LJP) with serum antibody responses to Actinobacillus actinomy. cetemcomitans. Clin. Exp. Immunol., 47 : 43-52, 1981.

56) Tai, C.C., McArthur, W.P., Baeni, P.C., Evian, C., Genco, R.J. and Taichman, N.S. : Serum neutralizing activity against Actinobacillus ac- 
tynomycetemcomitans leucotoxin in juvenile periodontitis. J. Clin. Periodontol., $8: 338-348$, 1981.

57) Williams, B.L., Ebersole, J.L., Spekter, M.D. and Page, R.C. : Assessment of serum antibody patterns and analysis of subgingival microflora of members of a family with a high prevalence or early-onset periodontitis. Infect. Immun., $49: 742-750,1985$.

58) Zambon, J.J., Christersson, L.A: and Slots, J. : Actinobacillus actinomycetemcomitans in human periodontal disease. Prevalence in patient groups and distribution of biotypes and serotypes within families. J. periodontole., 54 : 707-711, 1983.

59) Okuda, K., Naito, Y., Fukumoto, Y., Kimura, Y., Ishikawa, I., Kinosita, S. and Takazoe, I. : Bacteriological study of periodontal lesions in two sisters with juvenile periodontitis and their mother. Infect. Immun., $45: 118-121$, 1984.

60) Doty, S.L., Lopatin, D.E., Syed, S.A., Smith, F.N. : Humoral immune response to oral microorganisms in periodontitis. Infect. Immun., 37 : 499-505, 1982.

61）石川 烈：「歯周疾患の診断」ELISA 法の臨床応 用. 日本歯科医師会雑誌, 40 (7)：785-798, 1987.

62）岡村和則, 永井 淳, 熊沢 寛, 杉山雅昭, 水島 ゆみ, 光田由可, 高芝正悟, 栗原英見, 野村慶 雄, 村山洋二 : 歯周病関連細菌に対する血清 IgG 抗体 第 2 報 歯周病治療に伴う血清 IgG 抗体 の変動. 日歯周誌, $29: 146-100,1987$.

63）永井 淳, 岡村和則, 小林充治, 横山雅之, 熊沢 寛，杉山雅昭，栗原英見，野村慶雄，村山洋二 : 歯周病関連細菌に対する血清 $\mathrm{IgG}$ 抗体 第 1 報 歯周病の病状と $\operatorname{IgG}$ 抗体との相関. 日歯周誌, 29 : 132-145, 1987.

64）岡田 宏 : 若年性歯周炎をめぐって. 日本歯科医 師会雑誌，40：467-473，1987.

65) Bragd, L., Dahlén, G., Wikström, M. and Slots, J. : The capable of Actinobacillus actinomycetemcomitans, Bacteroides gingivalis and Bacteroides intermedius to indicate progressive periodontitis; a retrospective study. J. Clin. Per- iodontol., $14:$ 95-99, 1987.

66）松岡 直, 中村 弘, 杉浦 勉, 北川常広, 石川 栄治, 渡辺 武: 抗体の調整, 大沢利昭, 永井克 孝, 免疫生化学研究法, 東京化学同人, 東京, 1986, 1-10.

67）松元康治, 大久保慶二, 横山三男 : フローサイト メトリーを用いたヒト末梢血リンパ球膜抗原の分 析一正常人の抗原分布について一. 臨床免疫, $16: 862-872,1984$.

68）坂戸信夫 : 調節系としての免疫ネットワーク, 臨 床免疫 hand book，日本臨床社，1984，14-21.

69）William, E.P : 多田富雄 : 基礎免疫学 (下), 東 京大学出版社, 東京, 1986, 543-671.

70）小安重夫：増殖因子（インターロイキン）とリン パ球増殖, 今日の免疫学, 南江堂, 東京, 1985 , 117-119.

71）多田富雄, 浜岡利之: 免疫応答の調節, 岩波書店, 東京, 1984, 15-306.

72）桃井宏直：免疫産生過程とその調節機構, 臨床免 疫 hand book. 1984, 162-174.

73) Jeffrey, L. : The immune system in AIDS. 別冊 サイエンス, 92-104, 1986.

74) Okada, H., Kassei, Y., Kida, T. : T lymphocyte subsets in the inflamed gingiva of human adult periodontitis. J. Periodont. Res., 19 : 595 598, 194.

75) Seymour, G.J., Powell, R.N. and Davis, W.I. R. : Conversion of a stable T-cell lesion to a progressive B-cell lesion in the pathogenesis of chronic inflammatory periodontal disease : an hypothesis. J. Clin. Periodontol., $6: 267-277$, 1979.

76) Macker, B.F., Frosted, K.B., Robertson, P.B. and Levy, B.M. : Immunogloblin bearing lymphocytes and plasma cell in human periodontal disease. J. Periodont. Res., 12 : 37-45, 1977.

77) Seymour, G.J. and Greenspan, J.S. : The phenotypic characterization of lymphocyte subpoulations in established human periodontal disease. J. Periodont. Res., 14 : 39-46, 1979.

78）木田友信 : 歯周炎患者における免疫担当細胞の検 索一T リンパ球, B リンパ球, Fcレセプター保有 細胞について一. 日歯周誌, $24: 84-105,1983$.

79) Okada, H., Kida, T. and Yamagami, H. : Iden- 
tification and distribution of immunocompetent cell in inflamed gingiva of human chronic periodontitis. Infect. Immun., $41: 365-374,1983$.

80) Seymour, G.J., Crouch, M.S., Powell, R.N., Beckman, I., Zole, H., Bradley, J. and Bruns, G.F. : The identification of lymphoid cell subpopulations in sections of human lymphoid tissue and gingivitis in children using mano- clonal anibodies. J. Periodont. Res., 17 : 247256, 1982.

81) Cohen, R.L., Alves, M.E.A.F., Ostrega, M.S., Belcaster, G. and Chamber, D.A. : Topographic distribution of Thy-1 positive cell in epitherial tissues of balb/c mice. Archs. Oral Biol., 32 : 11-15, 1987. 